\title{
As curas milagrosas da Virgem Maria em Lourdes: a controvérsia médico-religiosa
}

\section{Lilian Sales}

\section{(2) OpenEdition}

1 Journals

Edição electrónica

URL: http://journals.openedition.org/aa/1770

DOI: $10.4000 /$ aa. 1770

ISSN: 2357-738X

Editora

Programa de Pós-Graduação em Antropologia Social (UnB)

\section{Edição impressa}

Data de publição: 1 julho 2016

Paginação: 153-172

ISSN: 0102-4302

\section{Refêrencia eletrónica}

Lilian Sales, «As curas milagrosas da Virgem Maria em Lourdes: a controvérsia médico-religiosa», Anuário Antropológico [Online], v.41 n. 1 | 2016, posto online no dia 05 junho 2018, consultado o 28 abril 2021. URL: http://journals.openedition.org/aa/1770 ; DOI: https://doi.org/10.4000/aa.1770

\section{(c) $)(1)(9$}

Anuário Antropológico is licensed under a Creative Commons Atribuição-Uso Não-Comercial-Proibição de realização de Obras Derivadas 4.0 International. 


\section{As curas milagrosas da Virgem Maria em Lourdes: a controvérsia médico-religiosa}

Lilian Sales

Unifesp

As curas milagrosas acontecidas no Santuário da Virgem Maria na vila francesa de Lourdes tornaram-se emblema do embate entre o catolicismo e o cientificismo positivista presente na Europa nas últimas décadas do século XIX. O Santuário mariano de Lourdes surgiu do relato da aparição de Nossa Senhora para a vidente Bernadette em 1856. A historiadora Ruth Harris (2002) demonstra o complexo processo de construçáo desse fenômeno, do momento em que a menina pastora teve a primeira visão da Virgem na grota até a formação de um santuário na modesta vila francesa, um dos maiores santuários marianos europeus desde finais daquele século.

Desde seu início, a aparição de Lourdes foi apropriada por representantes do clero, como padres da localidade, e posteriormente por iminentes representantes do catolicismo internacional. Esse fato, segundo a autora, contribuiu imensamente para a instituição do Santuário, atribuindo respeitabilidade a esse fenômeno com características pouco ortodoxas. Sobre a grota na qual a menina Bernadette teve sua primeira visão foi construída uma Igreja e, em torno dela, o Santuário da Virgem.

Já Elisabeth Claverie (2009) demonstra que o processo de reconhecimento das apariçốes foi bastante longo e marcado por acirradas disputas. A autora parte da primeira declaração da visão pela jovem adolescente, relatando como o processo de publicização e legitimação das apariçóes envolveu uma série de controvérsias, estando a legitimidade dos fenômenos em constante disputa. A aparição seguiu um longo trajeto político, sendo que vários dispositivos foram constituídos sobre a cena imediatamente posterior à aparição, marcada por poderes, opinióes contraditórias e disputas entre os agentes. A defesa dessas causas era constituída com base em equipamentos argumentativos e narrativos específicos e ligados a certos dispositivos de expressão, como a imprensa, os partidos, os jogos de opiniáo e as teorias de conhecimento.

A autora mostra o processo de conversão da crítica a formas específicas da modernização no contexto da aparição em uma crítica política ao princípio da modernidade. Como em relação à vidente Bernadette, cujo sentido político, social e religioso mudou ao longo desse processo, engajando a cada passo relaçóes 
diferentes e exercendo um caminho de subida na generalização, ${ }^{1}$ vários dispositivos e equipamentos argumentativos estavam envolvidos nesse processo, transformando a mensagem inicial contrária aos efeitos de um tipo de modernidade em uma guerra conservadora contra a modernidade.

Nossa pesquisa está situada nesse contexto histórico e analítico. ${ }^{2}$ Harris (2001) e Claverie (2009) consideram as apariçôes e a constituição do Santuário como um evento voltado para o futuro e náo como um produto social do passado, um resquício de um tipo de religiosidade "ultrapassada", forma como muitos analistas a haviam tratado até o momento. Sob essa perspectiva, deveremos nos debruçar sobre a controvérsia referente às curas milagrosas ocorridas no Santuário de Lourdes após o fim das aparições, quando o santuário já estava estabelecido e as apariçóes já haviam sido reconhecidas.

Além disso, as duas autoras demonstram como o santuário francês foi representativo do embate entre cientificistas e católicos na França do século XIX, tema que perpassa pela controvérsia a ser analisada neste artigo. Examinaremos uma cena específica no contexto das apariçôes de Lourdes: as curas milagrosas ocorridas no santuário, observando que dispositivos e estratégias discursivas alimentam a controvérsia em torno desses episódios. Focaremos as justificativas produzidas em defesa de posicionamentos por parte de agentes de diferentes áreas: médica, literária e católica. Nossa intenção será compreender o entroncamento, as articulaçóes e negociaçóes entre agentes e argumentos de origens diversas. Assim, nossa abordagem se utiliza da análise de controvérsias, com vistas à compreensão dos processos de produção de justificativas e moralidades em momentos de tensão social. ${ }^{3}$

Ao longo da pesquisa, identificamos os agentes envolvidos nessa controvérsia, especialmente aqueles que escreveram documentos sobre as curas, como livros e artigos. Observamos sobretudo os repertórios de justificativas produzidos por esses agentes nesses textos, cuja leitura foi o ponto de partida para a identificação dos argumentos com potencial de convencimento nessa controvérsia. Em seguida, observamos como (ou se) essas justificativas estariam presentes em outras arenas por onde os agentes identificados circulavam.

Os dados para esta pesquisa foram coletados em duas bibliotecas especializadas em estudos sobre temas religiosos na França. ${ }^{4}$ Foram analisadas obras de teólogos, cientistas e médicos referentes às curas de Lourdes, do final do século XIX e início do século XX, contendo documentos e pareceres de cientistas e teólogos sobre os casos de curas miraculosas. Algumas obras teológicas mais recentes foram também consideradas, sobretudo os seis volumes sobre Lourdes escritos pelo Pe. René Laurentin (1957-1961), iminente defensor das apariçóes marianas na atualidade. 
Na obra Lourdes, documents authentiques, o autor traz uma série de documentos autênticos sobre a manifestação. Além disso, foram consideradas obras literárias importantes sobre o santuário, como Lourdes, de Émile Zola (1995).

Para a identificação dos repertórios de justificativas e dispositivos, realizamos a leitura dessas obras, especialmente referentes ao período em que essa controvérsia estava ativa e a produção de textos a seu respeito foi mais volumosa, na última década do século XIX e nas primeiras décadas do século XX. O conceito de repertórios de crítica e justificação vem de Boltanski e Thévenot (1991). Para eles, a defesa dos posicionamentos em situaçóes de disputa ocorre por meio da formulação de justificativas ou de críticas pelos indivíduos, que aportam legitimidade a suas açôes e práticas discursivas. Assim, neste artigo nos deteremos nos repertórios de justificação presentes naquela controvérsia, bem como nos fundamentos de confiança acionados nos discursos, observando quais dispositivos e estratégias compóem os equipamentos argumentativos formulados. Segundo Boltanski, para se tornarem potentes, verossímeis e aderentes, as justificativas precisam acionar princípios de confiança e generalidade. Dessa maneira, começaremos a trilhar esse caminho no que se refere ao desvendamento da controvérsia sobre as curas milagrosas de Lourdes na França no século XIX.

Nossa análise se aproxima daquela realizada por Claverie, para quem a subida no processo de generalização 5 é parte fundamental na conquista de legitimidade das apariçóes da Virgem. ${ }^{6}$ Náo nos deteremos no processo de legitimação das apariçốes marianas, mas sim na disputa pela aquisição (ou não) de legitimidade das curas e dos milagres no santuário francês de Lourdes. Essa disputa se tornou uma controvérsia pública de grandes dimensões na França cerca de quatro décadas após a consolidação do Santuário nos Pirineus.

O século XIX é considerado inaugural por alguns estudiosos das apariçôes por ser o momento em que o clero dá uma nova utilização para essas manifestaçóes. Esse é um momento importante para as manifestaçôes da Virgem devido ao empenho de representantes da Igreja Católica no reconhecimento e na legitimação desses fenômenos. ${ }^{7}$ Não se trata de um investimento apenas em sua regulação e controle, embora este também estivesse presente, mas sobretudo nas apariçóes como fenômenos representativos da existência e da manifestação do extraordinário e do sobrenatural no mundo, em um contexto em que a ciência e a razão ganhavam espaço e legitimidade. As apariçóes de Nossa Senhora representam a fé contra o racionalismo e o positivismo. Assim, apesar da longa história dessas manifestaçóes no catolicismo, o século XIX representa um momento de organização de um padrão para esses fenômenos, processo no qual alguns agentes da Igreja assumem papel de destaque. 
Lourdes está inserida nesse processo, e podemos nos arriscar a dizer que esse é o santuário mariano onde o objetivo da Igreja em estabelecer um modelo de fé contra o cientificismo em voga naquele período foi o mais eficiente. ${ }^{8}$ Tais milagres e curas aconteceram após a aparição, intensificando-se no final do século XIX, período em que a Igreja Católica realizou um grande investimento na organização e divulgação do santuário na vila de Lourdes, e estendendo-se ainda durante a primeira metade do século XX.

Nossa intenção é compreender esse debate, mapeando os argumentos em defesa das curas construídos por médicos do período que relatam episódios milagrosos ocorridos no Santuário. Observaremos como são estruturadas e articuladas as narrativas das curas, buscando compreender como elas organizam um repertório plural de justificativas. Nessas narrativas, os atores se reportam a diversas gramáticas e moralidades para dar sustentação às justificativas produzidas favoravelmente à existência das curas milagrosas no Santuário de Lourdes. Observaremos como são formuladas essas justificativas e a quais moralidades elas se reportam para subir no processo de generalização, ganhando assim verossimilhança.

Nesse processo de subida na generalização, as evidências e a lógica médicocientífica tornam-se centrais. O modo como os agentes, clérigos e médicos católicos buscam legitimar as curas milagrosas por meio de um aparato das ciências médicas é uma importante questão que deverá ser explorada.

\section{O debate sobre o Santuário de Lourdes, suas curas e seus milagres}

Uma série de cientistas, sobretudo médicos e psiquiatras, produziram uma grande quantidade de livros, teses e artigos sobre os episódios milagrosos de Lourdes, alguns defendendo intensamente as curas, outros buscando desqualificá-las. Paralelamente, enquanto cientistas e médicos buscavam explicaçôes para os fenômenos de cura, multidôes de peregrinos assolados pelos mais diversos males físicos acorriam ao santuário mariano. O fascínio pelo Santuário de Lourdes e por suas curas era geral na França no final do século XIX. Isso se deve, em grande parte, à disputa na arena pública francesa a respeito do santuário e dos episódios extraordinários no local.

A característica distintiva do Santuário de Lourdes é o cuidado com os doentes e moribundos. Porém, ela não estava presente nas primeiras décadas do Santuário, não sendo relacionada a nenhuma mensagem da Virgem. Os doentes não tinham qualquer lugar de destaque nas primeiras peregrinações; a tradição das curas de Lourdes foi sendo construída conjuntamente pela hierarquia eclesiástica, com 
a participação das ordens e dos movimentos femininos, e somada às crenças e práticas da religiosidade local dos Pirineus.' A partir de então, já em 1880, Lourdes tornou-se "a peregrinação das curas milagrosas" (Harris, 2001).

Conforme destacado por Joachim Bouflet e Philippe Boutry (1997), o Santuário de Lourdes foi entấo organizado em torno das curas por meio da água que brotava da grota onde a Virgem apareceu para Bernadette. O santuário é repleto de piscinas, nas quais pacientes com diferentes males eram mergulhados. Devotos e doentes oravam diante da grota de onde brotava essa água e sobre a qual foi construída a Igreja. Peregrinaçóes eram realizadas a partir dos hospitais e sanatórios franceses, italianos, espanhóis e de outros países europeus. Trens lotados de pessoas doentes, acompanhados de enfermeiras religiosas, partiam em direçâo a Lourdes. Garrafas de água da grota, com o formato da Virgem de Lourdes, eram vendidas em todo o santuário.

Segundo Boutry, o "modelo francês" moldou dois tipos de manifestaçôes: as apariçóes que têm como foco o milagre, cujo exemplo é Lourdes, e as apariçóes em que o foco está nas mensagens, geralmente de caráter escatológico, cujo exemplo é La Salette. Embora em ambas as apariçóes os dois elementos - milagre e mensagem - estejam presentes, a essência da aparição está em apenas um deles. Em Lourdes, é a água milagrosa, como mencionamos, sendo a presença das curas milagrosas fundamental no Santuário. A grande tônica está na busca do milagre da cura.

Vale destacar, entretanto, que a conexão e a continuidade entre manifestaçóes da Virgem Maria ocorridas na França ao longo do século XIX foram estabelecidas pelos clérigos, como demonstrado por Gillet (1994), e não constitutivas dos fenômenos em si. Além disso, como já vimos, o empenho na legitimação da aparição de Lourdes e na constituição do santuário por parte dos clérigos e das ordens religiosas foi observado por duas especialistas sobre a aparição de Lourdes: Harris e Claverie.

Harris (2001) afirma que o Santuário de Lourdes foi imaginado pelos padres e pelas mulheres. A preocupação com o cuidado dos doentes foi ideia das mulheres, em um momento no qual a feminizaçáo do catolicismo era muito intensa. Movimentos e congregaçôes religiosas femininas de devoção à Virgem surgiram nesse período, como as Filhas de Maria e as Irmázinhas da Assunção, congregação que ainda hoje se ocupa dos doentes durante as viagens de trem para Lourdes. Já Claverie (2009) explicita o processo de apropriação da aparição de Lourdes em um modelo "antimodernidade", defendido ferrenhamente pela ala mais conservadora do catolicismo do período. 
Os três autores citados demonstraram que o Santuário de Lourdes e sua vocação para a cura estavam em consonância com um movimento de valorização da fé e do extraordinário realizados pelo clero francês durante a segunda metade do século XIX. Esse movimento se choca com os princípios do cientificismo positivista e do racionalismo em voga naquele período, e os milagres de Lourdes estão no centro dessa controvérsia entre ciência e religião, clericalismo e anticlericalismo presente na França no final daquele século (Gugelot, 2010; Harris, 2001). As hordas de doentes que se deslocavam ao santuário francês causavam constrangimento aos defensores do pensamento racional científico. $\mathrm{O}$ anticlericalismo, acompanhado do cientificismo positivista, gerava um clima de tensão em relação ao catolicismo. ${ }^{10}$

Assim, Lourdes tornou-se um lugar de afrontamento entre o pensamento religioso e o pensamento racional naquele período. De um lado, estavam médicos, cientistas, literatos chamados de "céticos", que se empenhavam em demonstrar o caráter ilusório das curas de Lourdes. Para eles, Lourdes representa o obscurantismo e a náo racionalidade, o resíduo de um mundo arcaico diante do cientificismo, da tecnologia e da modernidade. De outro lado, teólogos e sacerdotes empenhavamse em tornar o santuário e suas curas um baluarte da permanência da fé e do extraordinário no mundo.

Essa polaridade foi constituída por controvérsias que colocavam as curas e o santuário francês no centro das discussóes. As controvérsias em torno das curas milagrosas de Lourdes adentraram o universo acadêmico científico, a opinião pública e a literatura. Uma profusão de obras literárias e médicas e de artigos em jornais foi produzida sobre o tema, alguns adquirindo enorme repercussão, outros com menor penetração. O Santuário de Lourdes foi alvo de interesses de diversas ordens, compondo um importante tema em discussão na arena pública francesa na segunda metade do século XIX.

As obras literárias eram parte dessa controvérsia, que confrontava autores céticos (ou mesmo ateus, como Zola) e representantes do catolicismo. Zola escreveu uma obra sobre as peregrinaçóes e curas da Virgem em Lourdes. Sua metodologia na obra Lourdes foi a observação: o autor foi ao Santuário, acompanhou as peregrinaçóes, as curas e os relatos, usando essa experiência, cuidadosamente registrada em notas, na realização de sua obra. Para os autores naturistas, o registro de dados e de resultados de análises permitiria o acesso ao real. ${ }^{11}$ Antes da escrita da obra, Zola permaneceu um longo período no santuário francês; esteve em contato com peregrinos, clérigos e médicos do bureau de constataçóes médicas de Lourdes. 
A obra desse autor causou enorme impacto. Após sua publicação e o debate gerado em torno dela, mais de 100 médicos foram a Lourdes, e mais de 300 no início do século XX (Gugelot, 2010). Lourdes, por sua enorme repercussão, também produziu violentas respostas por parte dos defensores do santuário. ${ }^{12}$ Entretanto, os autores naturistas náo foram os únicos. Houve uma abundante produção literária sobre Lourdes. A versão do jornalista Henri Lassere, Notre Dame de Lourdes, publicada em 1869, foi considerada oficial pela hierarquia católica e amplamente divulgada. ${ }^{13}$

É com esse pano de fundo que a controvérsia sobre as curas de doentes no Santuário de Lourdes se desenvolveu. Em 1883 (cerca de quarenta anos após as apariçóes), foi estabelecido, na vila de Lourdes, o Bureau des Constatations Médicales (BCM) com o fim de examinar minuciosamente as reivindicaçôes de curas. Para isso, o bureau usaria de todo o aparato da medicina, com seus diagnósticos e exames, com vistas a reforçar a crença no caráter extraordinário das curas.

\section{O Bureau de Constataçóes Médicas de Lourdes}

Desde o século XVIII, após a encíclica De servorum Dei Beatificatione et beatorum canonizatione, publicada por Bento XIV, a hierarquia católica buscava estabelecer critérios de controle e condiçôes para a identificação e o posterior reconhecimento dos chamados "eventos extraordinários", como milagres, curas, apariçóes e visôes. ${ }^{14}$ Três critérios se destacaram: a gravidade da doença, a não ingestão de medicamentos e o caráter instantâneo e definitivo da cura.

Esses critérios foram apropriados pelo BCM na análise das curas. Anteriormente à instalação desse escritório, a comissão episcopal contava com a consultoria de um médico para a análise dos milagres. Harris (2001) destaca o ceticismo e cientificismo desse médico nas análises. Segundo a historiadora, a comissão episcopal conduzia as análises embasada apenas em alguns critérios de fé e as encaminhava ao Doutor Verguez. Este, por sua vez, adotava critérios científicos em seus pareceres, de modo que muitas das curas consideradas milagrosas pela comissão eram classificadas como "curas naturais" pelo médico. Para Verguez, a explicaçáo de parcela das curas no santuário não era a intervençáo da Virgem; vários casos foram por ele excluídos devido a sua explicação "natural".

A partir de então, análises com base em critérios médicos e científicos passaram, paulatinamente, a ser utilizados na avaliação da veracidade e do caráter sobrenatural dos eventos extraordinários. Exemplo disso foi a substituição dos padres, anteriormente responsáveis pela constatação das curas, pelos médicos no BCM (Harris, 2001). No momento da sua fundação, a maioria dos membros 
eram clérigos, mas já em 1900 havia quase exclusivamente médicos no escritório — a entrada em uma fase mais profissional aconteceu em 1891, quando os dados e levantamentos científicos passaram a dar o tom das avaliaçôes. O BCM ganhou ano a ano mais adeptos, e tornou suas análises cada vez mais rigorosas do ponto de vista científico.

A disputa entre médicos céticos e religiosos (muitos deles também médicos) era ampla e não se reduzia ao fato de Lourdes. A escola de medicina de Paris, por exemplo, era essencialmente anticlerical, e formava seus clínicos para intervir nos hospitais católicos, buscando laicizar seu pessoal e seus métodos. Existia um acirrado debate com as ordens religiosas, considerando-se que as instituiçóes deveriam ser retiradas das mãos das irmandades. A instituição do BCM de Lourdes se fez nesse contexto, representando um esforço da hierarquia católica para se posicionar no debate a partir dos termos e argumentos que eram potentes no universo das ciências. A utilização dos critérios científicos era uma forma de rebater as críticas de antimodernidade destinadas aos clérigos e ao catolicismo e suas crenças. As narrativas das curas eram estruturadas tendo por base os dados, pareceres médicos e exames clínicos, ou seja, todo um saber fazer associado às ciências médicas. A capacidade de generalização dessas narrativas, que atribuía legitimidade a episódios assumidamente singulares de cura, se dava por meio do uso dos critérios genéricos da medicina do período.

Entretanto, o BCM não foi resultado exclusivo da situação vivenciada na França no século XIX. Apesar de o contexto francês ser relevante, o pensamento racional e iluminista vinha influenciando a hierarquia católica desde o século XVIII, como na mencionada encíclica de Bento XIV. Existia um processo interno ao catolicismo buscando estabelecer critérios e maior rigor na avaliação de milagres, colocando-os sob a supervisão da Igreja.

Desde aquele momento, a discussão em torno do que é considerado "natural” ou "não natural” era central nas análises da dimensão milagrosa das curas, pois se precisava comprovar o caráter sobrenatural dos fenômenos. A partir da existência do BCM, essa concepção se fortaleceu, utilizando-se de critérios de análise pautados no rigor científico. A leitura das obras nos apontou que a categoria "natureza" associada às leis biológicas emergiu dessa controvérsia. Por oposição a ela, a busca do BCM era pelos eventos "não naturais", pelas curas que rompiam com as leis biológicas, ditas "leis da natureza". O excepcional, o milagre, seria caracterizado pelo rompimento do curso "natural" dos episódios. Nessa concepção, a natureza seria pautada por leis gerais, e o extraordinário seria representado pela ruptura dessas leis. 
Assim, apesar de sofrerem a evidente influência das escolas de pensamento, os critérios de análise produzidos por Bento XIV mantinham sua característica teológica, ou seja, eram critérios de fé estabelecidos doutrinariamente. Nesse aspecto, a qualificaçáo das curas como "naturais" ou "não naturais" estava relacionada ao desdobramento da concepção de milagre historicamente presente na teologia católica. A gramática sobre o que seria um milagre na teologia católica se fez presente nas justificativas de cura oferecidas pelo BCM.

A obra de Joachim Bouflet Une histoire des miracles mostra elementos desse repertório dos milagres no catolicismo. Desde os primórdios da religião, "a consciência religiosa chama de milagres os eventos que interrompem a marcha normal das coisas" (2008:17). O milagre, portanto, é conhecido como um sinal da intervenção divina que interrompe a ordem do mundo. A essa concepção de milagre no Ocidente vai sendo anexada a ideia do milagre como algo extraordinário, excepcional. Segundo o autor, tal concepção ganha força a partir do progresso científico e da evolução do discurso filosófico sobre a razão, sendo influenciada pelo iluminismo, pelo racionalismo e pelo cientificismo.

Diversos dispositivos vão se sobrepondo nessa gramática do milagre presente no catolicismo. A concepção de sobrenatureza bem como a possibilidade e presença das intervençôes divinas no mundo "natural" são centrais ao catolicismo. Uma das formas mais comuns de demonstração do poder de deus vem de suas intervençóes na ordem do mundo terrestre. Esse poder se manifesta como uma sobrenatureza, e nesse contexto ela é também observada, conjugando-se a uma visão de mundo iluminista e positivista, na qual a natureza é concebida como regida por leis gerais passíveis de ser apreendidas a partir do rigor científico. A natureza é representada pela presença de leis gerais e previsíveis; a sobrenatureza e o poder de deus evidenciar-se-iam, portanto, pela ausência de explicaçáo científica e pela ruptura no curso das leis naturais.

Assim, a partir do século XIX, o discernimento do fato milagroso passou a ser realizado com o aparato das ciências. Houve uma associação entre o que é excepcional e o que não é natural: excepcional seria tudo aquilo que não poderia ser explicado pelas leis da natureza. A interrupção da ordem, já anteriormente presente na concepção de milagre, passou a ser considerada "interrupçáo da ordem natural" ou das "leis da natureza", e os cientistas seriam as pessoas capazes de realizar esse discernimento por meio de uma metodologia positivista. Dessa maneira, apesar das intervençôes de diversas ordens, a concepção do milagre manteve elementos de sua concepção teológica inicial, relacionada à alteração da ordem e sendo avaliada com base nela. 
Além disso, os cientistas e médicos deveriam apenas demonstrar o caráter natural ou não natural de um evento; já a classificação do episódio como um milagre era repassada aos teólogos. A dimensão teológica permanecia decisória. Os médicos e cientistas avaliavam os episódios de cura, porém, sua classificação como milagrosos era repassada aos teólogos especializados do Vaticano. A decisão final permanecia nas máos da alta hierarquia do catolicismo.

\section{A avaliaçáo das curas pelo Bureau de Constataçóes Médicas}

Os casos de cura avaliados pelo BCM passam por três fases analíticas, para então ser constatada a sua dimensão "natural" ou "não natural". A primeira fase é a coleta de provas. Em seguida, os dados são avaliados por profissionais. Para cada relato de cura apresentado ao bureau é designado um médico da Associação Médica Internacional que acompanhará a evolução clínica do "curado". Os membros do BCM devem realizar uma avaliação clínica rigorosa do miraculado e organizar um dossiê o mais completo possível com os dados e as evidências coletados, a partir do qual será obtido o parecer final do comitê médico.

$\mathrm{Na}$ terceira fase, determina-se a característica da cura e a qualificação especial que lhe deve ser atribuída. Isso acontece no BCM de Lourdes, onde se reúnem médicos associados e convidados externos para discutir o dossiê composto de exames e pareceres médicos sobre o miraculado, desde seu histórico médico até os dados após o episódio da cura. Esse é o momento do veredicto por parte da equipe médica, que define a cura como natural ou como um evento cujas explicaçóes ultrapassam a natureza.

Todas as etapas analíticas são marcadas por uma aplicação aparentemente rigorosa dos métodos científicos de constatação existentes naquele período. Essa preocupação é tamanha que invalida a priori quaisquer relatos cujas evidências não possam ser coletadas e analisadas pela equipe médica. Apesar desse rigor, Lourdes é a aparição mariana que possui o maior número de milagres reconhecidos — aproximadamente 60 - devido aos esforços empreendidos pelo BCM, que verifica cada caso relatado pelos peregrinos.

\section{As narrativas de cura: validação científica}

Por meio das narrativas de cura ocorridas no Santuário de Lourdes, relatadas nas obras dos médicos responsáveis pelo BCM no final do século XIX e início do século XX, podemos constatar como eram realizadas essas análises e qual era o padrão narrativo adotado por eles. Começaremos pelas análises das curas. 
As curas consideradas milagrosas são exaustivamente documentadas pelo BCM. O trabalho realizado é de investigação médica profunda, iniciando-se pelo levantamento do histórico médico das pessoas que relatam ter sido curadas no Santuário de Lourdes ou após a ingestão da água da grota. Primordialmente, é necessário que o miraculado apresente-se ao bureau, onde é realizada uma primeira avaliação clínica e coletado o seu relato e, de preferência, também o de testemunhas da cura súbita.

A exata condição da doença no momento anterior à peregrinação a Lourdes é o mínimo considerado necessário para a avaliação de um relato, sendo esse levantamento, preferencialmente, bem mais detalhado. As narrativas mostram que essas análises avançam o mais anteriormente possível nos dados médicos dos miraculados, buscando compor um histórico médico completo do paciente. Trata-se de um trabalho de exaustiva investigaçáo, percorrendo hospitais e sanatórios, procurando médicos que tenham atendido ao miraculado antes da cura e coletando pareceres desses médicos, bem como de outras testemunhas capazes de relatar a condição de saúde do miraculado e a evolução de sua doença. Vários desses levantamentos acumulam dados médicos sobre a realizaçáo da peregrinaçáo e as condiçóes do paciente ao longo da viagem (como em geral estavam acompanhados, o testemunho do acompanhante era coletado). Todos esses elementos e dados compóem as narrativas de cura realizadas pelo BCM.

As curas relatadas na obra Mes conferénces sur les guérisons miraculeuses de Lourdes, do médico Auguste Vallet (1929), responsável pelo BCM nas primeiras décadas do século XX, são repletas de exames médicos, dados clínicos e laboratoriais e outros dados do histórico médico dos curados. A existência dessa documentação médica é condição primeira para a qualificação de uma cura por esse escritório. De fato, vários casos nas obras analisadas são descritos dessa forma, com abundância de dados e anotaçóes médicas, bem como de exames clínicos sobre as características da doença em cada etapa de sua evolução. Os relatos vão o mais distante possível no levantamento do histórico clínico dos miraculados; muitos deles apresentam exames e relatos do início da moléstia, que pode ser uma doença crônica ou um acidente que deixou sequelas dolorosas, reportando-se a décadas anteriores à cura no Santuário de Lourdes.

Muitas páginas são gastas com esse detalhamento descritivo. Por exemplo, o caso da miraculada Maria Luisa Arnaut, que ocupa as páginas 24 a 36 da obra, relata todo o quadro clínico, desde o início da doença até a cura diante da grota de Lourdes, sendo a descrição acompanhada de exames clínicos e de testemunhos das religiosas de um hospital em Montpelier, onde a paciente estava internada desde que havia perdido a capacidade de andar. Também a miraculada 
Paulette teve exaustivamente detalhado e comprovado o seu quadro clínico estando à beira da morte e já tendo recebido a extrema unção, foi subitamente curada ao beber a água da grota de Lourdes. Toda a obra é organizada seguindo esse padrão.

Os casos de cura de tuberculose, em todas as suas variaçóes, são especialmente ricos em dados sobre a evoluçáo da doença, pois os doentes de tuberculose passavam por vários hospitais e sanatórios. Citamos um exemplo: ${ }^{15}$

Cura de um Mal de Pott (tuberculose cervical)

Começa pela história da paciente, logo passando a seu histórico médico de tuberculose e internaçóes desde os 9 anos, durante 34 anos.

A história de todos os sintomas clínicos é passada, com datas, hospital no qual foi atendida, médicos que a receberam.

Todas as provas da doença são acumuladas a cada passagem da paciente pelos hospitais, como exames clínicos e laboratoriais e pareceres de médicos.

O caso de tuberculose evolui para o mal vertebral em 1927.

1927: a paciente apresenta os primeiros sintomas do mal vertebral, comprovado por exames.

1928: paciente a apoia-se para andar e sente fortes dores nas costas.

1929: a paciente sofre formação de escaras, sendo citado o nome dos cirurgiōes que a tratam.

As escaras eram enormes, medindo cerca de $7 \mathrm{~cm}$. Há a descrição detalhada de cada uma, de acordo com os pareceres de médicos e enfermeiros que cuidavam da paciente.

Por fim, traz testemunhos do estado lastimável da doente durante a viagem de trem desde Paris até Lourdes, realizada em uma maca, da qual náo tinha possibilidades de se levantar e na qual mal podia se mover devido às feridas (anotaçôes sobre Vallet, 1929:43-58).

Após um relato dramático das condiçóes moribundas em que se encontrava, a paciente é subitamente curada após se banhar nas piscinas de Lourdes, o que foi testemunhado por seus acompanhantes. Segundo a obra, uma hora após o banho a paciente estava no BCM, onde lhe retiraram a placa em que se apoiava, ainda suja de sangue e pus, e perceberam náo haver sequer uma ferida em seu corpo, apenas cicatrizes fechadas. 
O segundo critério importante para a avaliação do caráter "não natural" da cura é observado: o seu caráter súbito. As curas são instantâneas, trazendo, como consequência, a terceira característica que deve ser averiguada: a ausência de convalescência. Por esse motivo, o acompanhamento do miraculado continua após o relato, com vistas a observar a concretude da cura, seu caráter imediato e a ausência de recuperação paulatina. ${ }^{16}$ A produção de provas e evidências acontece de forma a permitir averiguar a presença dos critérios de análise dos milagres estabelecidos na encíclica De servorum Dei Beatificatione et beatorum canonizatione.

As narrativas de cura insistem em sua instantaneidade e completude. A compreensão da dimensão "não natural" é estabelecida por meio da contraposição àquilo que é considerado natural: o seguimento das leis biológicas. Por isso, as obras trazem longos esclarecimentos sobre as características das curas "naturais", das etapas de evolução do doente antes da cura completa. No caso citado, são explicadas as etapas clínicas do processo de cicatrização de feridas, com a descrição biológica detalhada de todas as fases até a cicatrização completa. Por meio da demonstraçáo do processo natural de cura, o autor busca corroborar o aspecto não natural do caso, afirmando sua dimensão extraordinária.

Ainda assim, o acompanhamento do curado pelo BCM tem continuidade após o episódio de cura. O objetivo é constatar se a cura foi definitiva, ou seja, se não se tratou de uma invenção ou sugestão do curado. Para isso é designado um médico e os exames, dados clínicos e pareceres são novamente documentados, compondo o dossiê que deverá ser apresentado à comissão avaliadora. Com em relação à paciente mencionada no exemplo anterior,

logo após o banho nas piscinas, ao apresentar-se no BCM, a doente andava sem dificuldade e sem dor, o exame da coluna vertebral não apontava nenhum ponto de dor. [...]

Nesse dia da apresentação ao escritório, ela pesava $34 \mathrm{~kg}$.

Um dos médicos do BCM foi designado para acompanhar a doente durante um ano em Paris. [...]

Colocou mês a mês o peso da ex-doente, totalizando [um aumento de] $17,5 \mathrm{~kg}$ em 11 meses.

Foi examinada um ano depois, e nenhuma dor vertebral foi constatada: "a doente sentia-se curada após 35 anos de sofrimentos. A tuberculose, em plena evolução, cessou sua progressão. Escaras de um palmo foram cicatrizadas instantaneamente. Não, essa cura não pode ser considerada um processo natural" (Vallet, 1929:65), afirma o autor (anotaçóes sobre Vallet, 1929:58-65). 
Após a coleta de dados e comprovaçôes ao longo de anos, e a sua organização no formato de processos, ocorre a avaliação dos dados por profissionais e especialistas que se reúnem com o intuito de analisar o dossiê sobre o episódio. O rigor científico é quase uma obsessão para a qualificação dos episódios de cura pelo BCM. Nesse sentido, as concepçôes de "natureza" e "não natureza" são fundamentais. Natural é aquilo que é cotidiano e que pode ser explicado pelo conhecimento médico e biológico, como no caso das cicatrizaçôes, em que "naturalmente" a cura acontece de forma gradual. Já quando foge às explicações conhecidas pelas ciências naturais e médicas, a cura é classificada como "não natural”. Natural é a cura que segue as leis biológicas gerais. É essa lei geral que informa a constituição da categoria de "natural", por oposição às curas "não naturais", que são excepcionais e singulares. Os médicos do BCM constatariam, seguindo esses procedimentos médico-científicos, a presença da sobrenatureza divina nos episódios "sem explicação natural".

As leis biológicas são um critério de validação que atribui generalidade aos eventos. Os atores, ao demonstrarem conhecimento sobre essas leis (discorrendo sobre suas etapas e características) e ao constatarem a singularidade dos episódios de cura narrados (pelo uso de critérios de validação científicos), conformam um processo de subida na generalidade desses eventos e, consequentemente, em sua legitimidade. A subida na generalidade acontece por meio da explicitação das leis biológicas gerais e da evidenciaçáo da inexistência da operacionalidade dessas leis nas curas relatadas. Ao cumprirem essas características singulares, elas podem consideradas "não naturais" nas narrativas em questão, evidenciando a presença e a intervenção da sobrenatureza divina no episódio. $\mathrm{O}$ extraordinário, como a cura súbita de uma ferida, é então detectado pela ausência do cumprimento das leis da natureza. $\mathrm{O}$ milagre, nessa concepção, não poderia ser explicado pelas leis gerais da natureza e por isso não poderia ser apreendido pelo arsenal das ciências médicas.

Os critérios científicos servem, então, como dispositivo para o engrandecimento desses episódios, sendo exaustivamente utilizados nas justificativas presentes nas narrativas. Ou seja, a capacidade de generalização das narrativas de cura está, em grande parte, em suas justificativas embasadas em critérios de validação científicos, que remetem a leis biológicas gerais e universais. Os critérios científicos seriam os dispositivos capazes de atribuir legitimidade aos episódios de cura analisados pelo BCM. 


\section{As narrativas de cura: entre os critérios científicos e o direcionamento teológico}

A busca pela explicação "não natural", apesar do uso exaustivo de dados e explicações científicas, também é informada por elementos da teologia católica. Essas narrativas intercalam momentos em que os dados médicos sobre o paciente são utilizados com os momentos em que os diálogos com a medicina e a biologia são estabelecidos, sendo obras produzidas por médicos e cientistas.

Embora parte importante do repertório de autoridade presente nas narrativas e em seus autores venha da ciência, a gramática da teologia católica conduz a linha argumentativa. Apesar de raramente as palavras "milagre" ou "cura sobrenatural" serem mencionadas, é a ela que os autores estão se referindo. Para isso, usam extensas citaçôes sobre o processo de cura em casos "naturais", como no exemplo do fechamento de feridas, estabelecendo um paralelo com as curas de Lourdes, nas quais esse aspecto corriqueiro, natural, não está presente, apresentando, pois, uma dimensão extraordinária.

A busca dos médicos do BCM é pela comprovação de que o extraordinário está presente no santuário, interferindo na ordem cotidiana da vida de algumas pessoas. Com esse fim, eles juntam um enorme arsenal de dados e provas que consideram capazes de evidenciar a presença do inexplicável naquele local. Por mais paradoxal que possa parecer, acumulam provas e dados científicos buscando demonstrar que alguns episódios seriam cientificamente inexplicáveis, pois não seguem as leis gerais da natureza. A ausência de explicaçáo contribuiria para demonstrar a dimensão extraordinária dos episódios.

Como visto, o milagre na teologia católica está relacionado à ruptura da ordem do mundo. E o arsenal científico serve para a demonstração dessa ruptura. Os elementos da ciência estão, em certa medida, a serviço da fé. O aparato da ciência serve para reforçar concepçóes de fé longamente presentes no catolicismo, como a concepção de milagre como algo que rompe a ordem do mundo - neste caso, com as leis biológicas universais.

Desde o momento em que médicos assumem o BCM, os termos científicos são dominantes no debate de ambas as partes. Toda a explanaçáo sobre as curas, o levantamento de dados e o acompanhamento do miraculado mostram o cuidado e o rigor científico dos médicos do BCM. Além disso, os autores das obras que narram os milagres são também médicos, preferencialmente com importante formação acadêmica. Os repertórios de justificativas são produzidos acionando todo esse aparato científico. 
A ligação desses médicos com o catolicismo é apenas percebida pela sua vinculação ao BCM. Em seus escritos e pareceres, fazem questão de esclarecer que a atestação do "milagre" deve ser realizada por teólogos, por religiosos, pela Igreja. Eles se eximem desse debate, apenas atestam as curas terem sido por "causas não naturais". Apesar disso, notamos que seus critérios científicos são também norteados pelos critérios teológicos, especialmente aqueles determinados pela encíclica de Bento XIV.

Aquilo que é considerado "não natural" pelos médicos do BCM é informado teologicamente, tendo relação com a concepção presente na encíclica em questão. Devido ao momento de tensão social e disputa, o rigor científico positivista é levado ao extremo pelos médicos no BCM. A legitimaçáo das curas de Lourdes é realizada por critérios da ciência, elaborados por atores com legitimidade no campo acadêmico.

A utilização de critérios científicos na legitimação das posiçôes teológicas é recorrente e central na controvérsia analisada. A sobrenatureza, a excepcionalidade das curas apenas poderia ser comprovada por meio do rigor científico. Desde então, a avaliaçáo científica passa a compor a gramática do milagre na Igreja Católica, influenciando as análises posteriores de milagres por parte da Igreja, seja por seus teólogos, seja por seus cientistas. Dessa maneira, o saber fazer científico, suas análises, seus critérios e suas titulaçôes passam a compor a gramática sobre os milagres no catolicismo.

Recebido em 11/06/14

Aprovado em 17/01/15

Lilian Sales é Professora de Antropologia na Universidade Federal de São Paulo. Tem desenvolvido pesquisas sobre religiosidade, principalmente nos temas: renovação carismática católica e apariçôes de Nossa Senhora. E-mail: lisales@usp.br 


\section{Notas}

1. Nesse processo, por exemplo, as declaraçóes da vidente foram corrigidas, deixando de ser tratadas por "visão" e sendo colocadas como "aparição", um objeto semântico mais manipulável e capaz de trazer possibilidades de alianças mais amplas e de novo tipo.

2. Esta pesquisa foi desenvolvida no âmbito do projeto "Alteridade e mediação: processos de construçáo do outro em universos católicos e protestantes no Brasil e na África” (processo Fapesp no 2008/107580).

3. Latour nomeia esses períodos de tensão de controvérsias.

4. Parte do levantamento da documentaçáo foi realizado na Biblioteca do Centro de Estudos dos Fatos Religiosos, ligada à Escola de Altos Estudos em Ciências Sociais. Outro levantamento foi realizado na Biblioteca Du Saulchoir, pertencente à ordem dos dominicanos, em Paris.

5. Boltanski e Thévenot (2006) afirmam que a legitimidade de argumentos e posicionamentos seria conquistada por meio de seu potencial de generalidade. A generalização é parte importante do processo de dessingularização de eventos ou causas. Nesse processo, os argumentos e as justificaçóes devem estabelecer alguma relação com princípios gerais para que sejam capazes de produzir verossimilhança. A possibilidade de generalizaçáo dos discursos está relacionada a sua capacidade de mobilizar a força coletiva, por isso é preciso que eles percam seu caráter singular. A análise realizada por Claverie sobre as apariçóes de Lourdes aproxima-se da proposta teórico-metodológica desses autores, compreendendo os dispositivos acionados nos repertórios de justificação capazes de aportar verossimilhança aos eventos das apariçóes.

6. A autora se debruça sobre essa questão em dois estudos de referência na antropologia francesa sobre as apariçóes marianas: o primeiro sobre as apariçōes marianas no povoado de Medjugorje, na antiga Iugoslávia, e o segundo sobre a constituição do Santuário de Lourdes, no século XIX.

7. A apropriação das apariçôes marianas como um modelo de fé por um grupo de clérigos na França durante a segunda metade do século XIX já foi anteriormente abordada (Sales, 2013).

8. A obra de Harris mostra que o processo de formação desse santuário foi bastante complexo, envolvendo outros agentes importantes além dos clérigos e das ordens religiosas - a vidente Bernadette, por exemplo. Náo queremos neste artigo passar a falsa impressão do mérito exclusivo de agentes ligados à Igreja Católica quanto a esse fato, mas enfatizar o papel de destaque desses agentes ao longo daquele processo.

9. Gillet (1994) destaca a importância da ação da Igreja Católica na constituição do modelo de aparições de Nossa Senhora. Segundo ele, há uma rede de clérigos que se envolve com as manifestaçóes e se engaja no reconhecimento e na divulgação do "fato sobrenatural que ocupa toda a França", estabelecendo relaçóes entre as apariçóes ocorridas na Rue du Bac (Paris), em La Salette e em Lourdes. Especialmente sobre 
La Salette, o autor demonstra a importância do envolvimento do clero da regiáo e de pessoas de credibilidade que estáo convencidas da veracidade das apariçóes, como o bispo de Grenoble. Ainda segundo esse autor, é essa mesma rede que estabelece a conexão entre La Salette e outras manifestaçóes ocorridas pouco antes na França.

10. Áreas que historicamente eram de domínio das ordens religiosas, os institutos educacionais e os hospitais passaram por processos de laicização. $\mathrm{O}$ ensino tornouse laico e os hospitais administrados pelas ordens religiosas sofreram intervenções de especialistas em suas práticas. A laicização e as intervençôes ocorreram no final do século XIX, muito próximo ao momento de constituição do Santuário de Lourdes. Além de perder espaço nas instituiçóes, a religiáo era constantemente taxada de obscurantista e acusada de impedir o desenvolvimento e o progresso da ciência e da tecnologia.

11. Zola foi o mais influente representante do naturismo, reclamando uma perspectiva científica nas obras literárias pela utilização de um método composto pela objetividade da descrição dos fatos, exatidão na observação e investigação total dos fenômenos a serem descritos (Gugelot, 2010).

12. De acordo com Gugelot (2010), que analisou a controvérsia literária sobre as apariçóes e curas de Lourdes, a primeira edição da obra de Zola se esgotou em dois meses. Ela foi prontamente desqualificada pelos críticos literários católicos em quatro artigos na revista jesuíta Études, entre outras respostas.

13. Segundo Harris, 142 edições de Notre Dame de Lourdes foram publicadas em sete anos. A obra foi traduzida em 24 línguas até 1900.

14. Desde a Contrarreforma, a questão do controle sobre a religiosidade popular e suas crenças vinha sendo colocada pela hierarquia católica. Porém, a partir do século XVIII, com Bento XIV, critérios para o discernimento dos milagres foram criados.

15. Como o relato completo é longo, náo cabendo aqui a sua citação completa, optamos pela utilização de nossas anotações de leitura.

16. A recuperação paulatina classificaria o episódio como uma "cura natural", por seguir o curso "natural" de recuperação clínica do paciente.

\section{Referências}

BOLTANSKI, Luc \& THÉVENOT, Laurent. 1991. De la justification: les économies de la grandeur. Paris: Gallimard.

BOUFLET, Joachim. 2008. Une histoire des miracles: du Moyen Age à nos jours. Paris: Seuil.

BOUFLET, Joachim \& BOUTRY, Philippe. 1997. Un signe dans le ciel: les apparitions de la Vierge. Paris: Bernard Grasset.

CLAVERIE, Elisabeth. 2009. "Parcours politique d'une apparition: le cas de Lourdes". Archives des Sciences Sociales des Religions, 145:109-128. 
GILLET, Claude. 1994. La rumeur de Dieu: apparitions, prophéties et miracles sous la restauration. Paris: Imago.

GUGELOT, Fredéric. "Les deux faces de Lourdes". 2010. Archives de Sciences Sociales des Religions, 151:213-228.

HARRIS, Ruth. 2001. Lourdes. Paris: Jean Claude Lattes.

LAURENTIN, René. 1957-1961. Lourdes, documents autentiques. Paris: Lethielleux. 7 v.

SALES, Lílian. 2013. "A legitimação das apariçōes da Virgem Maria: estratégias e agências”. Etnográfica, 17(2):317-339.

VALLET, Auguste. 1929. Mes conférences sur les guérisons de Lourdes. Paris: Tequi.

ZOLA, Émile. 1995. Lourdes. Paris: Folio. 


\section{Resumo}

Analisaremos neste artigo parte do debate médico-científico instaurado em torno das curas milagrosas no Santuário Mariano de Lourdes no final do século XIX e na primeira metade do século XX na França. Nossa intenção é mapear os argumentos presentes em livros e artigos do período que relatam episódios de curas milagrosas ocorridas no santuário. Privilegiaremos as obras escritas por médicos, observando como são estruturadas as narrativas das curas e por meio de quais mecanismos de expressão elas são articuladas, buscando compreender como os atores organizam um repertório plural de justificativas das curas. Diante do aumento da legitimidade das ciências desde o século XIX, demonstraremos a centralidade de critérios científicos de validação dos milagres e curas, o que levou à instalação, em Lourdes, do Bureau de Constataçôes Médicas, que realizaria análises médico-científicas dos relatos de cura no santuário. Para essa análise, nos utilizaremos da controvérsia como conceito-chave norteador do argumento do artigo.

Palavras-chave: Curas milagrosas, Lourdes, controvérsia, aparições marianas, Igreja Católica.

\section{Abstract}

This paper analyzes a part of the scientific discussion around the miraculous cures in the Marian Sanctuary of Lourdes in the late 19th century and in the first half of the 20th century in France. Our intention is to map the arguments supported in books and articles of the period that describe episodes of miraculous cures at the sanctuary. The research gives priority to the works written by scientists and doctors, observing the structure of the narratives of cure and the mechanisms of expression by which they are articulated. Also, we aim to understand how the actors organize a plural repertoire of justifications of cures in these narratives. The research demonstrates the centrality of the scientific validation of miracles and cures, which lead to the installation the Bureau of Medical Findings in Lourdes in order to conduct scientific analyses of the miraculous cures. The idea of controversy will be a key concept in this paper.

Keywords: miraculous cures, Lourdes, controversy, Our Lady's apparitions, Catholic Church. 